\title{
In-situ Bioremediation of Multiple Heavy Metals Contaminated Farmland Soil by Sulfate-Reducing Bacteria
}

\author{
Ying Lv ${ }^{1,2,3,4}$, Xuezhe Zhu ${ }^{1,3,4}$, Mingjiang Zhang,3,4,5*, \\ Xingyu Liu ${ }^{1,3,4,5 * *}$, Jianlei Wang ${ }^{1,3,4,5}$ \\ ${ }^{1}$ National Engineering Laboratory of Biohydrometallurgy, GRINM Group Corporation Limited, Beijing \\ ${ }^{2}$ School of Metallurgical and Ecological Engineering, University of Science and Technology, Beijing \\ ${ }^{3}$ GRINM Resources and Environment Tech. Co., Ltd., Beijing \\ ${ }^{4}$ General Research Institute for Nonferrous Metals, Beijing \\ ${ }^{5}$ GRIMAT Engineering Institute Co., Ltd., Beijing
}

Received: 13 April 2021

Accepted: 17 August 2021

\begin{abstract}
Heavy metal pollution of farmland soil deteriorates the cultivated land quality, and adversely affects the growth, yield, and quality of crops. Besides, it hampers food safety, and poses a tremendous threat to human health. In this study, an in-situ bioremediation process was investigated in maize planting areas by spraying sulfate-reducing bacteria solution based on previous studies. The altered basic physical and chemical properties of heavy metals in soil were studied using the Tessier sequential extraction technique to investigate the efficiency of the bioremediation process. The environmental effects of the bioremediation process were also explored by investigating the crop characteristics. The analysis of microbial species composition was used to explore the influence of exogenous microbes on microbial composition in farmland soil. The outcomes of remediation experiments showed that the sulfate-reducing bacteria could stabilize heavy metals in soil, inhibit the uptake of heavy metals by plants, improve the quality of maize products and promote the growth of maize plants. In this study, we investigated the in-situ bioremediation of multiple heavy metals contaminated farmland soil using sulfate-reducing bacteria. The outcomes of the study revealed the unique advantages of bioremediation technology in practical application of heavy metals contaminated farmland soil.
\end{abstract}

Keywords: multiple heavy metals, farmland, sulfate-reducing bacteria, bioremediation, community structure

*e-mail: zmj0630@163.com

**e-mail: wellwoodliu@163.com 


\section{Introduction}

Automobile exhaust, household garbage and sewage irrigation resulting from unreasonable mining are the major sources of heavy metal pollution in farmland soil $[1,2]$. The majority of the heavy metals are present in the topsoil of the farmland, which could not be restored to its originally non-polluted state within a brief period of time. This results in severe ecological imbalance $[3,4]$. Furthermore, several characteristic features of heavy metal pollution, such as multi-source, surface aggregation, imperceptibility, hysteresis, irreversibility [5], greatly influence the crop growth, the number, and community structure of soil microbes. Besides, as the heavy metal can enter the body through the food chain, it adversely affects human health via biological enrichment [6]. Thus, it is essential to reduce the heavy metal pollution of farmland soil and explore the remediation technology for soil treatment in accordance with the local environment $[7,8]$.

Bioremediation of heavy metals in soil is an environment-friendly technology, which has been widely practiced with encouraging results $[9,10]$. In bioremediation technology, the biological metabolic activity of functional microbes to reduce heavy metals' level so that the polluted soil environment is restored to its original state. Bioremediation primarily includes phytoremediation, microbial remediation, animal remediation and combined remediation [11]. Among them, microbial remediation technology uses active microbes to absorb, precipitate, oxidize or reduce heavy metals in the soil to decrease the concentration and toxicity of heavy metal pollution [12-16]. Compared with the physical and chemical remediation technologies, bioremediation is cost-effective, convenient to operate, and causes no secondary pollution and lesser disturbance to the soil. Thus, bioremediation possesses obvious economic and ecological benefits [17].

Microbial remediation technology includes ectopic bioremediation and in-situ bioremediation. Ectopic bioremediation refers to the removal of contaminated soil via a centralized treatment, that includes bioreactor and solid phase treatment. This treatment process could be strictly controlled, to achieve a better treatment effect. However, ectopic bioremediation remarkably affects the soil environment and has a high treatment cost. Thus, it is not suitable for treating large contaminated areas [18]. On the other hand, in-situ bioremediation uses soil microbes and inorganic nutrients. It promotes the stabilization/solidification of heavy metals in soil without altering the original soil [19]. Compared with other methods, it is cost-effective and convenient, causing minimum interference and destruction to the pollution site [20].

In this study, farmland in a typical industrial and agricultural developed area in Guangxi, China, was selected as site for the study. The solution containing sulfate-reducing bacteria was sprayed into the remediation area to study the bioremediation effects of these bacteria on farmland soil contaminated with multiple heavy metals. These heavy metals primarily included potentially toxic elements, such as $\mathrm{Cd}, \mathrm{Cr}$, $\mathrm{Cu}, \mathrm{Sb}, \mathrm{Zn}, \mathrm{Pb}$, and metalloid As. The bioremediation effects were evaluated by analyzing the growth characteristics of maize plants, such as plant height, length, circumference, and weight. In addition, highthroughput sequencing technology was used to investigate the bacterial community diversity and changes in bacterial species composition during the bioremediation process. This study aimed to explore a sustainable way of farmland development by restoring farmland soil. The data from this study will provide a platform and theoretical basis for the treatment of heavy metals contaminated farmland.

\section{Experimental}

\section{Study Site and Sampling}

The experimental site was located at Nandan County, Hechi City, Northwest Guangxi Province, China (Fig. 1) (N2446'56.3", E107³7'54.3"), 0 20 cm deep topsoil layer in the planting area was analyzed.

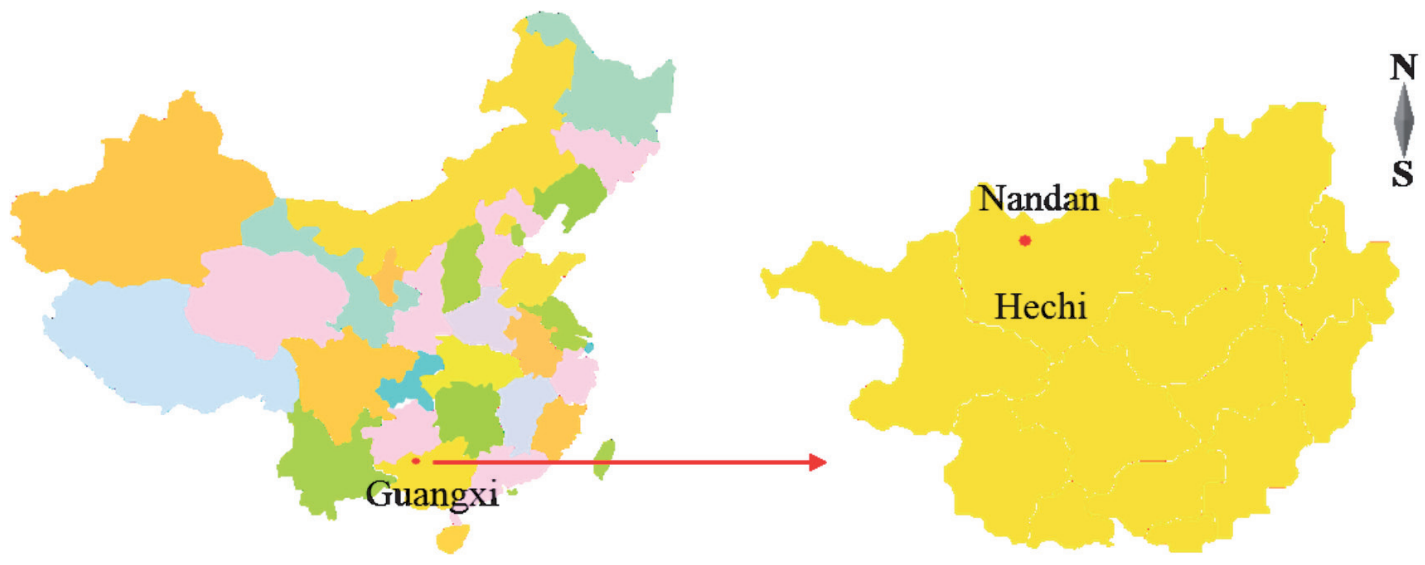

Fig. 1. The study location and sample site distribution. 


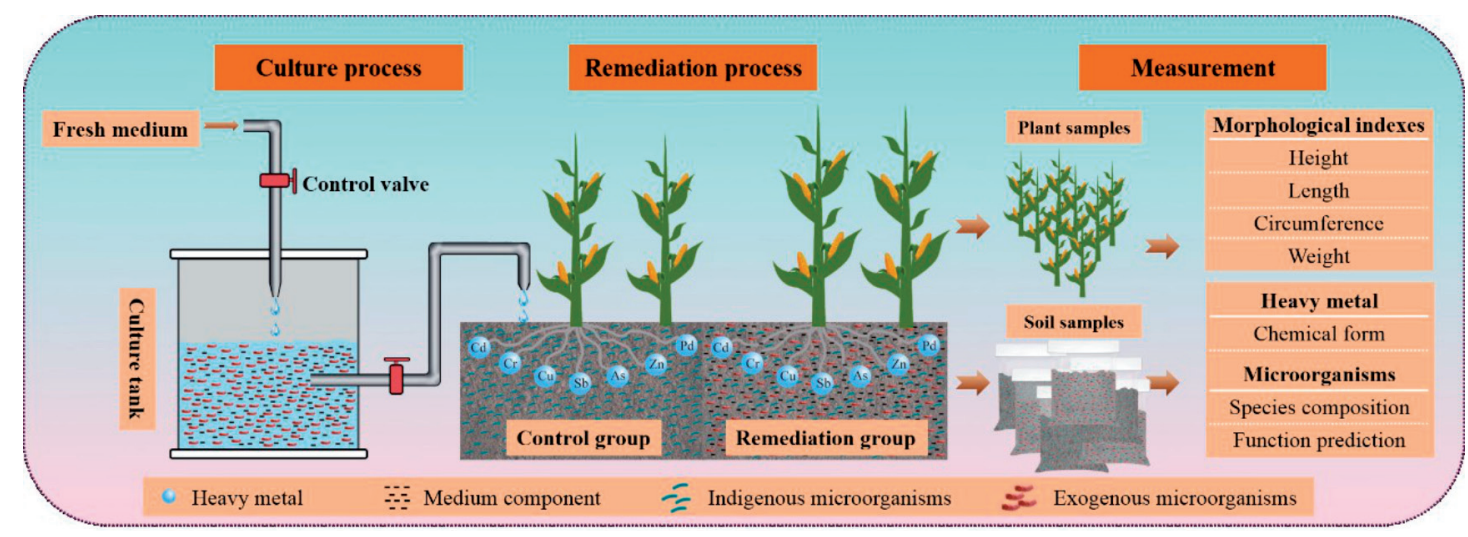

Fig. 2. The flow chart of the experiment.

The maize plants were planted during the first week of June 2018 and harvested in the first week of October 2018. The duration of the experiments was 115-120 days. The soil samples from farmland were collected using grid sampling, and each sample weighed about $5 \mathrm{~kg}$. At the time of harvest, 100 maize samples were collected from the control and remediation groups to evaluate the relevant plant indices. Apart from the plant height $(15,35,42$ days), other plant parameters were tested post-harvest (115-120 days after planting). The specific experimental process is shown in Fig. 2.

After all samples were transported to the laboratory for further analysis. Gravels were removed from the soil samples and dried naturally, ground, and sieved through (100 mesh nylon sieve) for reserve use. Maize grains were fried and ground to $<1.0 \mathrm{~mm}$. All the samples were stored in a glass desiccator until further analysis.

\section{Materials}

The bacterial test strains were from a class of sulfate-reducing bacteria (Desulfovibrio are the dominant functional bacterium) that were isolated from activated sludge [21], preserved in the National Engineering Laboratory of Biohydrometallurgy, China. The test bacteria were cultured in a minimal salt medium (MSM), and the specific component of the medium is shown in Table 1.

\section{Experimental Design}

In this study, Zheng Dan 985 variety of maize was used. Two parallel plots were set in the control group and the remediation group. Each experimental area was $25.0 \mathrm{~m} \times 20.0 \mathrm{~m}$, and the field was managed consistently. In addition, $1 \mathrm{~m}$ crop protection belts were left between each plot. In this study, a random block design was adopted. Maize plants were sprayed with sulfate-reducing bacteria immediately after maize plantation and supplemented with bacterial medium twice a month during the crop growth.

At the maturity stage, maize plant growth and development indices were estimated. Fifty representative maize plants were selected from control and remediation groups. The plant height, length, and weight of these maize plants were measured. In addition, maize plant circumference was measured using an electronic digital display vernier caliper.

\section{Measurement}

In this study, the soil $\mathrm{pH}$ was determined in soil solution (soil and water in 1:2.5 ratio) using the glass electrode method (Orion 3 Star pH Benchtop, Thermo Scientific, America) [22]. The $\mathrm{pH}$ meter was calibrated using a standard liquid before each measurement. The total amount of metal in soil and maize plants was quantified using the " $\mathrm{HNO}_{3}$-HF" digestion system. $0.2 \mathrm{~g}$ of solid samples were added to $6 \mathrm{~mL} \mathrm{HNO}_{3}(\mathrm{GR})$ and $2 \mathrm{~mL}$ HF (GR) for digestion in Microwave Digestion System (Multiwave PRO, Anton Paar, Germany). The contents of heavy metals, i.e., $\mathrm{Cd}, \mathrm{Cr}, \mathrm{Cu}, \mathrm{Sb}, \mathrm{Zn}, \mathrm{Pb}$ and As were determined using an Inductively Coupled

Table 1. Ingredient of Minimal salt medium (MSM).

\begin{tabular}{|c|c|}
\hline Ingredient & Content \\
\hline $\mathrm{Na}_{2} \mathrm{HPO}_{4}$ & $4 \mathrm{~g} \cdot \mathrm{L}^{-1}$ \\
\hline $\mathrm{KH}_{2} \mathrm{PO}_{4}$ & $1.5 \mathrm{~g} \cdot \mathrm{L}^{-1}$ \\
\hline $\mathrm{NH}_{4} \mathrm{Cl}$ & $1 \mathrm{~g} \cdot \mathrm{L}^{-1}$ \\
\hline $\mathrm{MgSO}_{4} \cdot 7 \mathrm{H}_{2} \mathrm{O}$ & $0.2 \mathrm{~g} \cdot \mathrm{L}^{-1}$ \\
\hline $\mathrm{CaCl}_{2}$ & $0.02 \mathrm{~g} \cdot \mathrm{L}^{-1}$ \\
\hline $\mathrm{FeSO}_{4} \cdot 7 \mathrm{H}_{2} \mathrm{O}$ & $0.03 \mathrm{~g} \cdot \mathrm{L}^{-1}$ \\
\hline $\mathrm{NaNO}_{3}$ & $1 \mathrm{~g} \cdot \mathrm{L}^{-1}$ \\
\hline Trace element solution & $1 \mathrm{~mL} / \mathrm{L} \mathrm{medium}$ \\
\hline $\mathrm{H}_{2} \mathrm{O}$ & $1000 \mathrm{~mL}$ \\
\hline $\mathrm{pH}$ & $7.0 \sim 7.5$ \\
\hline
\end{tabular}

* Per $100 \mathrm{~mL}$ trace element solution consists of the following components: $0.25 \mathrm{mg} \mathrm{CoCl} \cdot 6 \mathrm{H}_{2} \mathrm{O}, 0.37 \mathrm{mg}$ $\left(\mathrm{NH}_{4}\right)_{6} \mathrm{Mo}_{7} \mathrm{O}_{24} \cdot 4 \mathrm{H}_{2} \mathrm{O}, 4.0 \mathrm{mg} \mathrm{CuSO} \cdot \cdot 5 \mathrm{H}_{2} \mathrm{O}, 5.7 \mathrm{mg} \mathrm{H}_{3} \mathrm{BO}_{3}$, $4.3 \mathrm{mg} \mathrm{MnSO} \cdot 5 \mathrm{H}_{2} \mathrm{O}, 4.3 \mathrm{mg} \mathrm{ZnSO} \cdot \cdot 7 \mathrm{H}_{2} \mathrm{O}$. 
Plasma Optical Emission Spectrometer (ICP-OES) (Agilent 700 Series, Agilent Technologies, America). The chemical form experiments were performed as per the Tessier sequential extraction procedure [23]. To ensure the accuracy and reliability of analysis, each analysis included two test samples, blank reagents, and standard references (National Research Center for Standard Materials GBW07429). The analysis of microbial diversity was undertaken by Sangon Bioengineering (Shanghai) Co., Ltd.

\section{Results and Discussion}

\section{The Chemical Transformation of Heavy Metals in Farmland Soils}

The toxicity of heavy metals in soil depends on the chemical forms of metals [24]. Heavy metals can be divided into exchangeable form, carbonate, Fe-Mn oxidation, organic matter, and the residual state as per their bioavailability and activity [25]. The exchangeable form of heavy metals is either absorbed by plants or transformed into other chemical forms. This form of heavy metal has the highest activity and toxicity in the soil environment, followed by the carbonate state [26]. The form of residual state of the toxic metals is most stable, as it binds most firmly to the soil. However, these metal forms are hardly adsorbed by the plants or transformed into other forms of heavy metals. Thus, the residual form of heavy metals is least toxic to the environment [27]. It is worth noting that the low activity chemical forms of heavy metals could transform to the exchangeable state in a dynamic equilibrium with altered physical and chemical properties of soil [28, 29]. The stabilization effect alters the chemical form of heavy metals in the soil using the metabolic activities of soil microbes. It transforms heavy metals into a stable state with low toxicity, migration, and bioavailability. The remediation effect was evaluated by quantifying the stable state of heavy metals in the samples during the bioremediation process. The ability of sulfate-reducing bacteria to solidify heavy metals in farmland soil was correlated to microbial abundance and remediation time. This necessitated the assessment of migration and transformation of heavy metals in a particular time interval in farmland soil under the influence of sulfatereducing bacteria.

The percentages of each chemical form of $\mathrm{Cd}$, $\mathrm{Cr}, \mathrm{Cu}, \mathrm{Sb}, \mathrm{As}, \mathrm{Zn}$ and $\mathrm{Pb}$ in the farmland soil in the control and remediation group are shown in Fig. 3. As shown, the chemical forms of $\mathrm{Cd}$ and $\mathrm{Cr}$ were primarily residual, and the content of the other four chemical forms of heavy metals was low. In soil, $\mathrm{Cu}$ and As were present primarily in $\mathrm{Fe}-\mathrm{Mn}$ oxidation and organic matter state, and $\mathrm{Sb}$ and $\mathrm{Pb}$ in $\mathrm{Fe}-\mathrm{Mn}$ oxidation state, organic matter, and residual state. The percentage of $\mathrm{Zn}$ in all forms was relatively average, but the content of the FeMn oxidation state was the highest. Thus, several heavy metals were primarily present in one of the latter three forms in the soil. However, the content of exchangeable state directly utilized by plants was relatively low. And heavy metals in this form were still at the risk of being enriched by plants.

Due to the action of sulfate-reducing bacteria, the residual $\mathrm{Cd}$ and $\mathrm{Sb}$ showed the most apparent changes, as their percentages increased from $72.2 \%$ to $96.9 \%$ and $48.1 \%$ to $74.6 \%$, respectively, in the remediation

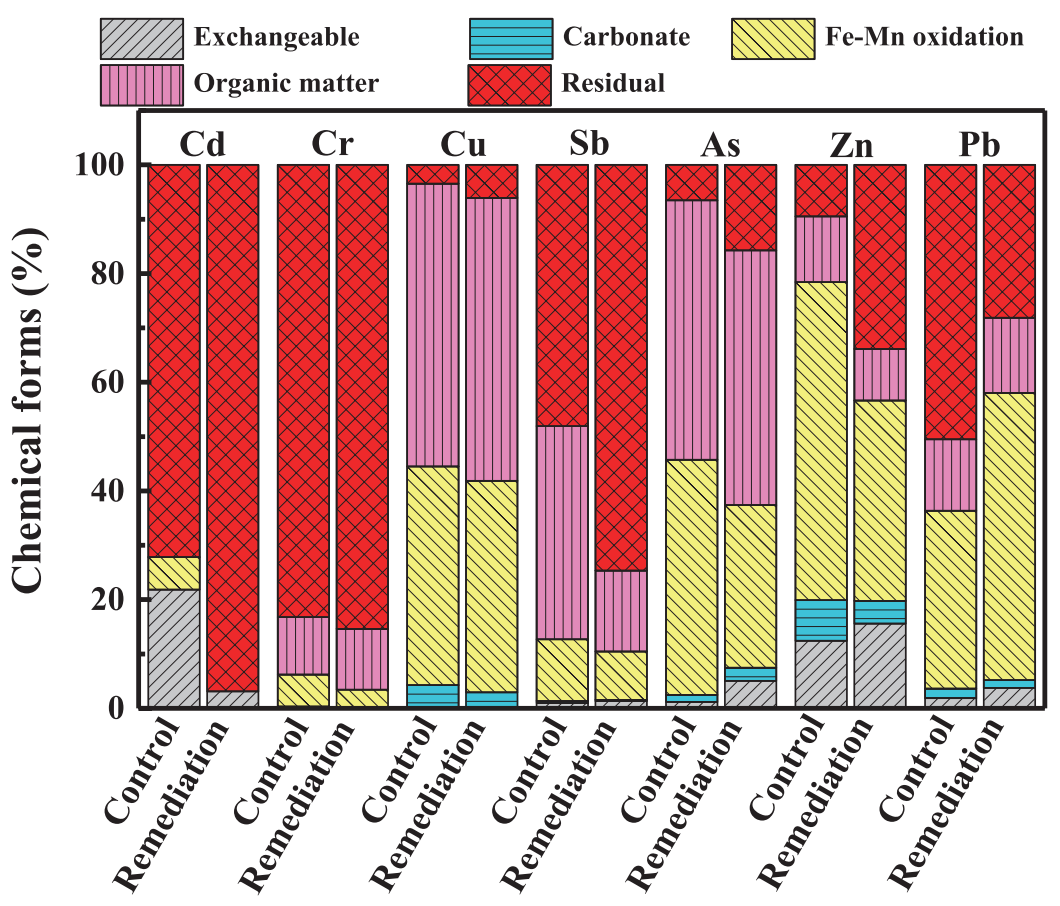

Fig. 3. Chemical form of heavy metals in control and remediation groups. 
group. The results indicated a significant stabilization of $\mathrm{Cd}$ and $\mathrm{Sb}$ in soil. Concurrently, we observed that the proportion of $\mathrm{Cr}$ in carbonate and $\mathrm{Fe}-\mathrm{Mn}$ oxidation state decreased, while the proportion of $\mathrm{Cr}$ in the latter two relatively stable forms increased. A similar trend was observed in $\mathrm{Cu}$ levels. The chemical form of As was determined, and the results showed that the proportion of Fe-Mn oxidation state decreased by $13.3 \%$, while the content of the residual state increased by $9.2 \%$. This indicates an insignificant difference in the amount of heavy metals, which was converted from a relatively unstable state to a relatively stable state. Compared with the control group, the percentage of carbonate, Fe-Mn oxidation, and organic matter state of $\mathrm{Zn}$ in the remediation group significantly decreased, and the residual content increased by $24.1 \%$. $\mathrm{Pb}$ showed the lowest stabilization effect, wherein the exchangeable, carbonate and organic matter states did not change significantly. However, Fe-Mn oxidation increased by $20.1 \%$, and the residual state decreased by $22.4 \%$. In other applications of the preserved strain, we observed that this class of sulfate-reducing bacteria could stabilize $\mathrm{Pb}$ in soil with a noticeable efficiency [21], which may be related to the site and soil characteristics. In conclusion, except $\mathrm{Pb}$, compared with the control group, the stable state increased, and the active state decreased for all the heavy metals in the remediation group with a significant stabilization/solidification effect, reducing the risk of heavy metal pollution in farmland soil. This suggests that sulfate-reducing bacteria could be used for the stabilization/solidification of these heavy metals to remediate similarly contaminated sites, reduce the bioavailability of heavy metals.

\section{Basic Physical and Chemical Properties of Soil}

Basic physical and chemical properties of the soil in control and remediation group are shown in Table 2. The bioremediation experiments showed improvement in the soil acidity as $\mathrm{pH}$ increased from 5.99 to 6.30 . It might be due to the alkali production and acid consumption because of the growth and metabolism of sulfate-reducing bacteria, which inhibited acidification and improved the environmental $\mathrm{pH}$ [21]. The sulfur content did not change significantly. In addition, the contents of available potassium, available phosphorus, basic nitrogen and organic matter in the soil were all increased. The specific promotion values were $22.21 \mathrm{mg} \cdot \mathrm{kg}^{-1}, \quad 7.47 \mathrm{mg} \cdot \mathrm{kg}^{-1}$, and $34.99 \mathrm{mg} \cdot \mathrm{kg}^{-1}$, respectively, with the increase rates of $90.54 \%, 29.44 \%$, and $18.09 \%$. As per the outcomes, bioremediation provides the nutrient elements to crops, and effectively improves the soil fertility. Therefore, the bioremediation technology with sulfate-reducing bacteria can effectively stabilize and solidify the harmful heavy metals in the contaminated soil, and improve the soil structure, making the local soil more suitable for crop growth.

\section{Heavy Metal Content in Maize}

Due to the different degree of participation of various heavy metals in crop plants, the plants show different enrichment effects of various heavy metals, that is, the absorption of different heavy metals in maize is inconsistent. The heavy metal content in the harvested maize plant is shown in Table 3. Apart from $\mathrm{Cd}$, which could not be detected in both groups, the contents of heavy metals in maize grains of the other six heavy metals were significantly reduced after bioremediation; however, $\mathrm{Sb}$ and As levels were undetectable postbioremediation process. $\mathrm{Cr}, \mathrm{Cu}, \mathrm{Zn}$, and $\mathrm{Pb}$ content decreased by $38.78 \%, 38.34 \%, 31.37 \%$, and $64.66 \%$, respectively. It indicates that sulfate-reducing bacteria may inhibit plant's absorption of heavy metals in soil. Besides, sulfate-reducing bacteria may solidify and stabilize the heavy metals in the soil, reducing the risk of plant absorption. These results were consistent with the change in the chemical form of heavy metals in the sulfate-reducing bacteria-treated soil from a relatively unstable state to a relatively stable state. Heavy metals that plants could absorb were reduced, so the level of heavy metals detected in the matured crops showed an apparent trend of reduction. This shows that sulfatereducing bacteria can effectively reduce the content of harmful heavy metals in maize plants to attain safe plantations.

\section{Growth Characteristics of Maize}

When heavy metals enter crop plants, they will affect the enzyme system, carbon and nitrogen metabolism, photosynthesis, mesophyll cell structure,

Table 2. Basic physical and chemical properties of the study site in control and remediation.

\begin{tabular}{|c|c|c|}
\hline Parameters & Group & Control group \\
\hline $\mathrm{pH}$ & $5.99 \pm 0.57$ & $6.30 \pm 0.28$ \\
\hline Available potassium content $\left(\mathrm{mg} \cdot \mathrm{kg}^{-1}\right)$ & $24.53 \pm 1.20$ & $46.74 \pm 2.69$ \\
\hline Available phosphorus content $\left(\mathrm{mg} \cdot \mathrm{kg}^{-1}\right)$ & $25.37 \pm 1.45$ & $32.79 \pm 0.28$ \\
\hline Basic nitrogen content $\left(\mathrm{mg} \cdot \mathrm{kg}^{-1}\right)$ & $193.41 \pm 22.37$ & $228.40 \pm 11.46$ \\
\hline Sulphur content $(\%)$ & $0.23 \pm 0.01$ & $0.18 \pm 0.06$ \\
\hline
\end{tabular}


Table 3. Heavy metal content in maize $\left(\mathrm{mg} \cdot \mathrm{kg}^{-1}\right)$.

\begin{tabular}{|c|c|c|c|c|}
\hline \multirow{2}{*}{ Elements Group } & \multicolumn{2}{|c|}{ Control group } & \multicolumn{2}{c|}{ Remediation group } \\
\cline { 2 - 5 } & Coverage & Error & Coverage & Error \\
\hline $\mathrm{Cd}$ & - & - & - & 0.07 \\
\hline $\mathrm{Cr}$ & 0.49 & 0.04 & 0.30 & 0.20 \\
\hline $\mathrm{Cu}$ & 3.73 & 0.25 & 2.30 & - \\
\hline $\mathrm{Sb}$ & 0.71 & 0.06 & - & - \\
\hline $\mathrm{As}$ & 0.78 & 0.06 & - & 3.40 \\
\hline $\mathrm{Zn}$ & 78.58 & 4.55 & 53.93 & 0.47 \\
\hline $\mathrm{Pb}$ & 1.33 & 0.19 & & 0.06 \\
\hline
\end{tabular}

etc., thus making the growth characteristics change under different conditions. Therefore, when evaluating the remediation effect of heavy metal contaminated farmland soil, plant characteristics can be used as a reliable index.

The maize plant height during the different experimental periods is shown in Fig. 4. Plant height is an important indicator for evaluating the quality of maize plants [30]. The results showed that 15 days after plantation, the average plant height of maize in the control group was $15.73 \mathrm{~cm}$, and in the remediation group, it was $24.87 \mathrm{~cm}$. After 35 and 42 days of plantation, the plant height in the remediation group increased by $9.70 \mathrm{~cm}$ and $4.67 \mathrm{~cm}$, respectively. Thus, the results demonstrated the efficiency of sulfatereducing bacteria in bioremediation of heavy metals contaminated farmland soil as these bacteria reduced soil environmental pollution and improved crop quality simultaneously.

The maize plant growth parameters, i.e., maize length, maximum circumference, gross weight, and net weight in different groups, were analyzed (Fig. 5). We found that the length of the maize plants increased by $32.69 \%$, and the maximum circumference increased

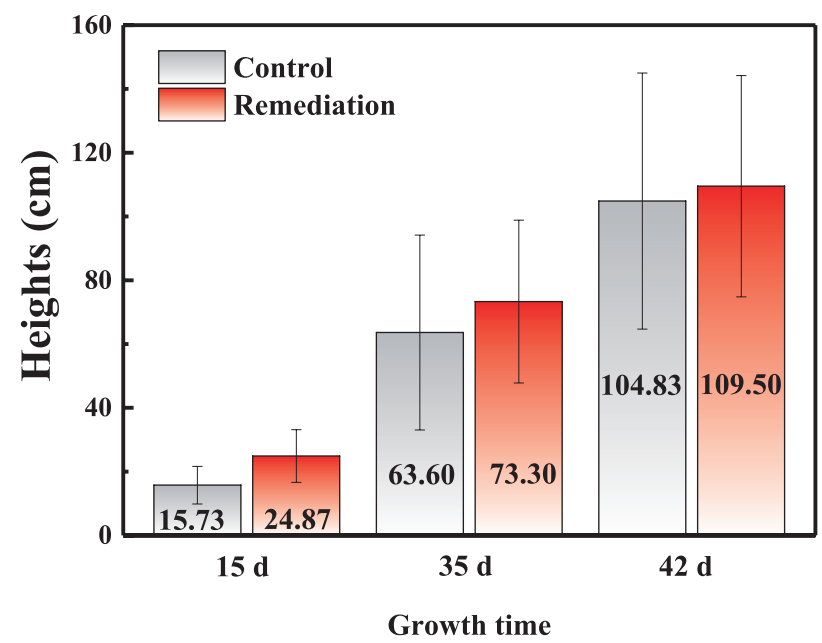

Fig. 4. Comparison of maize plant height in different periods. from $12.27 \mathrm{~cm}$ to $15.17 \mathrm{~cm}$ compared to the control group, with an improvement of $23.63 \%$. In addition, the gross and net weight of maize increased by $58.29 \mathrm{~g}$ and $46.03 \mathrm{~g}$, respectively, with an increase ratio of $43.09 \%$ and $44.37 \%$. Thus, the comprehensive evaluation of plant height, length, maximum circumference, gross weight, and net weight of maize plants indicated that sulfate-reducing bacteria could effectively improve the growth characteristics. These effects were remarkably higher than the control group, especially the difference between net weight and gross weight. In summary, crop yields and crop growth can be effectively improved by spraying sulfate-reducing bacteria solution into heavy metals contaminated soil under the conditions as in the current study.

\section{Changes of Community Structure}

The Venn diagram can be used to elucidate the number of common and unique OTUs between soil samples and reflect the difference in bacterial species composition between the samples at the OTU level (Fig. 6) [31, 32]. Out of the three groups (IS: background of initial soil; C1-2: parallel samples from control group; R1-2: parallel samples from remediation group),
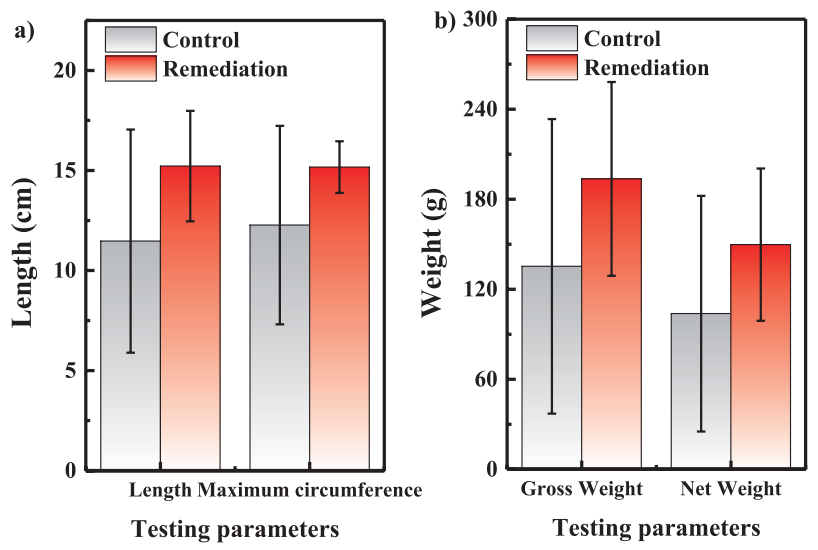

Fig. 5. Other growth indicators in control group and remediation group. 


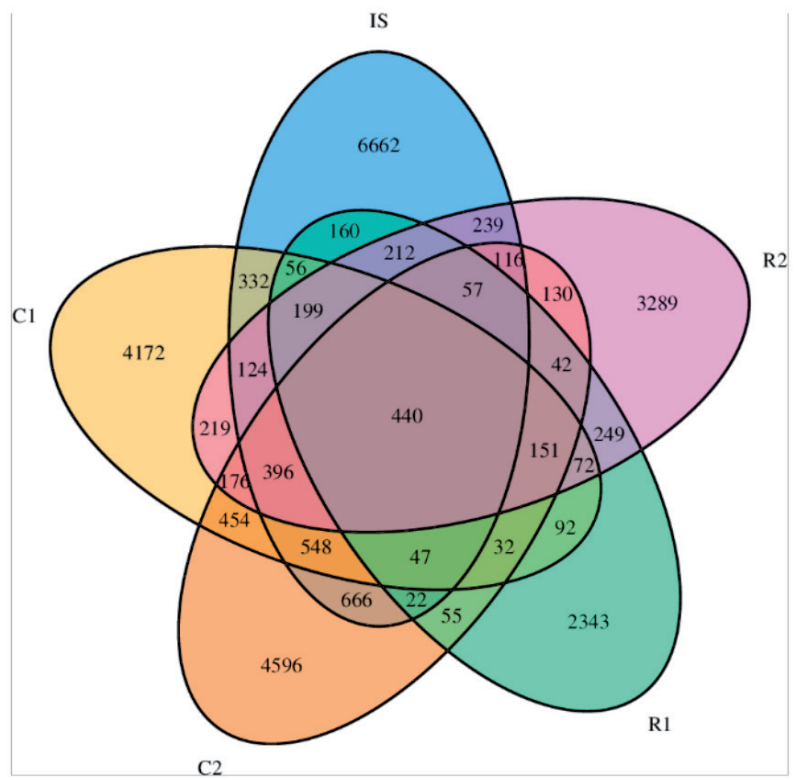

Fig. 6. Venn diagram of soil bacteria at the OTU level (ISbackground of initial soil; C1, C2-parallel samples taken from control group; R1, R2-parallel samples from remediation group).

IS had the highest OTUs and thus the most abundant bacterial communities in all the three samples. The total OTUs of bacteria in C1, C2, R1, and R2 was 440, and the unique OTUs in C1, C2, R1, and R2 were 4172, 4596,2343 , and 3289, respectively. This indicates that the bioremediation process altered the bacterial species composition in the in-situ soil at the OTU level. Still, the difference between the parallel groups was relatively less, while the remediation and the control group had a significant difference. This indicates that the bacterial community was altered in the bioremediation process. Besides, exogenous sulfate-reducing bacteria altered the soil environment, thus causing the change of microbial community composition in the soil.

According to outcomes of the functional prediction, the situation of one or more samples at a higher level of function can be known, and the functional structure of samples at a higher level can be observed [33]. In this study, the histogram of functional structure distribution based on COG is shown in Fig. 7. As shown in the figure, the majority of the active functional genes of the bacteria in the control and remediation groups were involved in energy production and conversion, amino acid transport and metabolism, carbohydrate transport and metabolism, translation, cell wall/membrane/envelope biogenesis, and signal transduction mechanisms. Overall, functions between the experimental groups did not differ significantly, as both the groups showed a slight difference in the enriched functions. For instance, amino acid transport and metabolism, carbohydrate transport and metabolism, and cell wall/membrane/envelope biogenesis were relatively active characteristics related to the bacterial activities in the remediation group. This suggests that the soil structure is not significantly affected during the entire remediation process, and the

\section{Distribution Barplot}

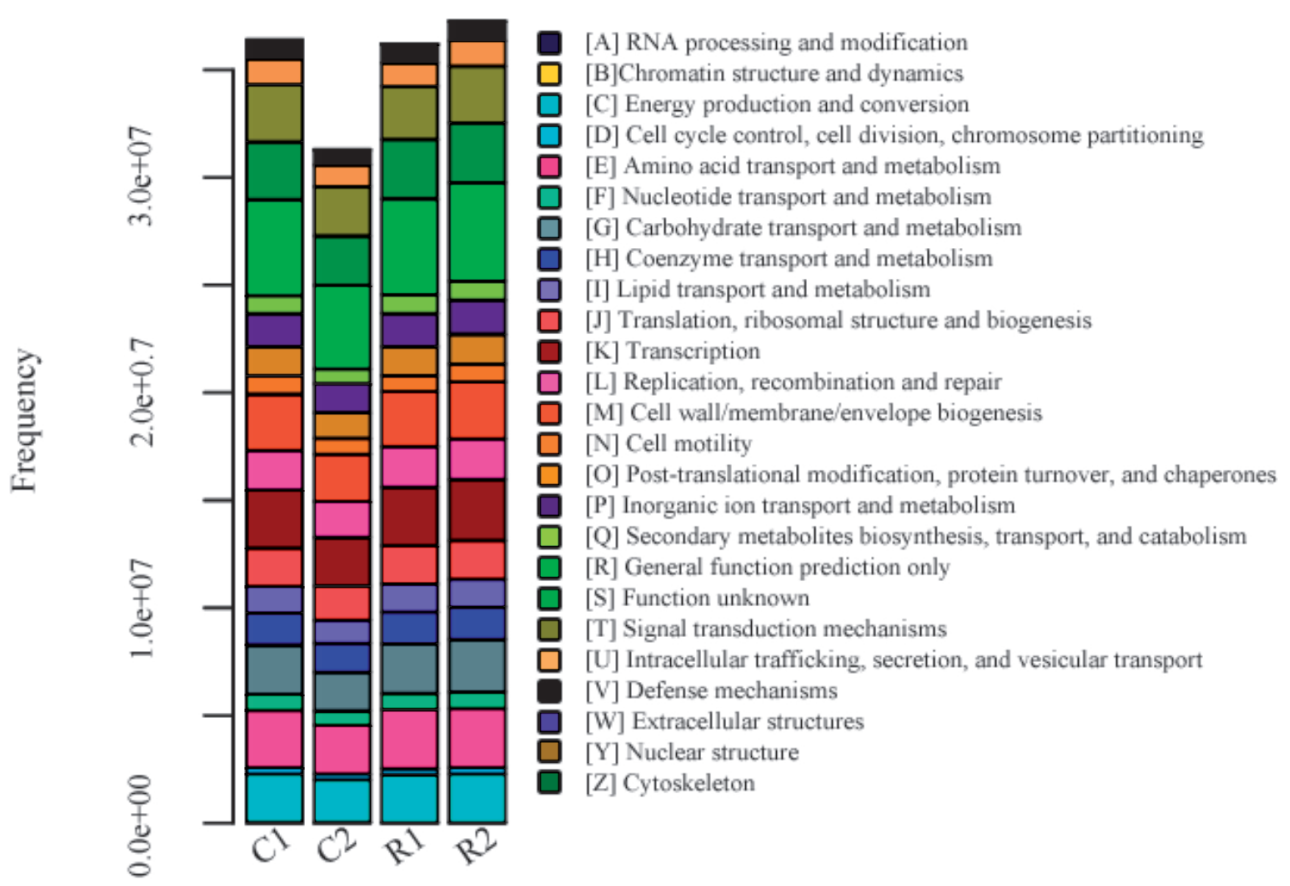

Fig. 7. Histogram of functional structure distribution based on $\mathrm{COG}(\mathrm{C} 1, \mathrm{C} 2$-parallel samples from control group; R1, R2-parallel samples from remediation group). 
normal biological metabolism of the original ecosystem can be maintained. It also showed that the application of sulfate-reducing bacteria caused insignificant disturbance to the local environment and can be considered a potential bioremediation agent that can be safely applied to farmland for soil bioremediation.

\section{Conclusions}

The current study demonstrated the efficiency of sulfate-reducing bacteria in bioremediation of heavy metals contaminated farmland soil. The Tessier sequencing extraction experiment validated that the $\mathrm{Cd}$, $\mathrm{Cr}, \mathrm{Cu}, \mathrm{Sb}, \mathrm{Zn}$, and metalloid As heavy metals were transformed from relatively unstable to stable chemical forms. The percentage of residual $\mathrm{Cd}$ increased from $72.2 \%$ to $96.9 \%$, and $\mathrm{Sb}$ increased from $48.1 \%$ to $74.6 \%$. The physical and chemical properties of soil were monitored, and the outcomes validated that the bioremediation process could effectively improve soil fertility in the experimental area. In addition, the results of the study showed that the sulfate-reducing bacteria remedied the heavy metal pollution in soil and improved the quality of crops. Besides, these bacteria played an important role in producing safe crops based on the evaluation of the content of heavy metals in maize grains and the growth characteristics of the maize plants, such as height, length, circumference, and weight. Venn diagram was used to analyze the differences in the species composition of samples from different groups at the OTU level, and the functional structure was analyzed. This study provides the theoretical basis for stabilizing toxic and harmful heavy metals using bioremediation technology, facilitating the deep utilization and detoxication of the heavy metals contaminated farmland soil.

\section{Acknowledgments}

This project is financially supported by the National Natural Science Foundation of China [grant numbers U1402234, 41573074 and 51974279], the National Key Research \& Development Program of China [grant numbers 2018YFC18018, 2018YFC18027 and 2019YFC18059], KeJunPing [2018] No. 159, the Guangxi Scientific Research and Technology Development Plan [grant numbers GuikeAB16380287 and GuikeAB17129025], which are greatly appreciated.

\section{Conflict of Interest}

The authors declare no conflict of interest.

\section{References}

1. CAMESELLE C., PENA A. Enhanced electromigration and electro-osmosis for the remediation of an agricultural soil contaminated with multiple heavy metals. Process Safety and Environmental Protection, 104, 209, 2016.

2. FAN J., CAI C., CHI H., REID B.J., COULON F., ZHANG Y., HOU Y. Remediation of cadmium and lead polluted soil using thiol-modified biochar. J Hazard Mater, 388, 122037, 2020.

3. DENG M., ZHU Y., SHAO K., ZHANG Q., YE G., SHEN J. Metals source apportionment in farmland soil and the prediction of metal transfer in the soil-rice-human chain. $\mathrm{J}$ Environ Manage, 260, 110092, 2020.

4. LIU L., LI W., SONG W., GUO M. Remediation techniques for heavy metal-contaminated soils: Principles and applicability. Science of The Total Environment, 633, 206, 2018.

5. DOLEV N., KATZ Z., LUDMER Z., ULLMANN A., BRAUNER N., GOIKHMAN R. Natural amino acids as potential chelators for soil remediation. Environ Res, 183, 109140, 2020.

6. KUMAR S., PRASAD S., YADAV K.K., SHRIVASTAVA M., GUPTA N., NAGAR S., BACH Q.V., KAMYAB H., KHAN S.A., YADAV S., MALAV L.C. Hazardous heavy metals contamination of vegetables and food chain: Role of sustainable remediation approaches - A review. Environ Res, 179 (Pt A), 108792, 2019.

7. MA Y., LI X., MAO H., WANG B., WANG P. Remediation of hydrocarbon - heavy metal co-contaminated soil by electrokinetics combined with biostimulation. Chemical Engineering Journal, 353, 410, 2018.

8. RONGGUO SUN J.Y., PINHUA XIA, SHENGLI WU, TAO LIN, YIN YI Contamination features and ecological risks of heavy metals in the farmland along shoreline of Caohai plateau wetland, China. Chemosphere, 254, 126828, 2020.

9. PAUL T., SAHA N.C. Environmental Arsenic and Selenium Contamination and Approaches Towards Its Bioremediation Through the Exploration of Microbial Adaptations: A Review. Pedosphere, 29 (5), 554, 2019.

10. PENG W., LI X., SONG J., JIANG W., LIU Y., FAN W. Bioremediation of cadmium- and zinc-contaminated soil using Rhodobacter sphaeroides. Chemosphere, 197, 33, 2018.

11. ZERAATKAR A.K., AHMADZADEH H., TALEBI A.F., MOHEIMANI N.R., MCHENRY M.P. Potential use of algae for heavy metal bioremediation, a critical review. J Environ Manage, 181, 817, 2016.

12. LI Y., LIAO X., LI W. Combined sieving and washing of multi-metal-contaminated soils using remediation equipment: A pilot-scale demonstration. Journal of Cleaner Production, 212, 81, 2019.

13. LAHORI A.H., GUO Z., ZHANG Z., LI R., MAHAR A., AWASTHI M.K., SHEN F., SIAL T.A., KUMBHAR F., WANG P., JIANG S. Use of Biochar as an Amendment for Remediation of Heavy Metal-Contaminated Soils: Prospects and Challenges. Pedosphere, 27 (6), 991, 2017.

14. LIU X., YANG L., ZHAO H., WANG W. Pyrolytic production of zerovalent iron nanoparticles supported on rice husk-derived biochar: simple, in situ synthesis and use for remediation of $\mathrm{Cr}(\mathrm{VI})$-polluted soils. Sci Total Environ, 708, 134479, 2020 
15. LUNA J.M., RUFINO R.D., SARUBBO L.A. Biosurfactant from Candida sphaerica UCP0995 exhibiting heavy metal remediation properties. Process Safety and Environmental Protection, 102, 558, 2016.

16. OTUNOLA B.O., OLOLADE O.O. A review on the application of clay minerals as heavy metal adsorbents for remediation purposes. Environmental Technology \& Innovation, 18, 100692, 2020.

17. HAN H., CAI H., WANG X., HU X., CHEN Z., YAO L. Heavy metal-immobilizing bacteria increase the biomass and reduce the $\mathrm{Cd}$ and $\mathrm{Pb}$ uptake by pakchoi (Brassica chinensis L.) in heavy metal-contaminated soil. Ecotoxicol Environ Saf, 195, 110375, 2020.

18. O'CONNOR D., PENG T., ZHANG J., TSANG D.C.W., ALESSI D.S., SHEN Z., BOLAN N.S., HOU D. Biochar application for the remediation of heavy metal polluted land: A review of in situ field trials. Sci Total Environ, 619, 815, 2018.

19. LIU S.J., LIU Y.G., TAN X.F., ZENG G.M., ZHOU Y.H., LIU S.B., YIN Z.H., JIANG L.H., LI M.F., WEN J. The effect of several activated biochars on Cd immobilization and microbial community composition during in-situ remediation of heavy metal contaminated sediment. Chemosphere, 208, 655, 2018.

20. GNANASUNDAR V.M., AKSHAI RAJ R. Remediation of inorganic contaminants in soil using electrokinetics. phytoremediation techniques, Materials Today: Proceedings, Available online: https://www.sciencedirect. com/science/article/pii/S2214785320318125 (accessed on 9 April 2020).

21. YAN X., LIU X., ZHANG M., CUI X., ZHONG J., HU X. Remediation of heavy metal pollution by sulfate reducing bacteria (SRB) isolated from activated sludge in lead-zinc smelter slag. Microbiology China, 46 (8), 1907, 2019.

22. Soil Testing - Part 2: Method for determination of soil $\mathrm{pH}$ (NY/T 1121.2-2006), Agricultural industry standard of the people's Republic of China.

23. TESSIER A., CAMPBELL P.G.C., BISSON M. Sequential Extraction Procedure for the Speciation of Particulate Trace Metals. Analytical Chemistry, 51 (7), 844, 1979.

24. ZHANG C., SHAN B., ZHU Y., TANG W. Remediation effectiveness of Phyllostachys pubescens biochar in reducing the bioavailability and bioaccumulation of metals in sediments. Environ Pollut, 242 (Pt B), 1768, 2018.

25. ZHANG J., LI H., ZHOU Y., DOU L., CAI L., MO L., YOU J. Bioavailability and soil-to-crop transfer of heavy metals in farmland soils: A case study in the Pearl River Delta. South China, Environ Pollut, 235, 710, 2018.

26. WANG G., PAN X., ZHANG S., ZHONG Q., ZHOU W., ZHANG X., WU J., VIJVER M.G., PEIJNENBURG W.J.G.M. Remediation of heavy metal contaminated soil by biodegradable chelator-induced washing: Efficiencies and mechanisms. Environmental Research, 186, 109554, 2020.

27. ZHAI X., LI Z., HUANG B., LUO N., HUANG M., ZHANG Q., ZENG G. Remediation of multiple heavy metal-contaminated soil through the combination of soil washing and in situ immobilization. Sci Total Environ, 635, 92, 2018.

28. WANG L., YANG D., LI Z., FU Y., LIU X., BROOKES P.C., XU J. A comprehensive mitigation strategy for heavy metal contamination of farmland around mining areas Screening of low accumulated cultivars, soil remediation and risk assessment. Environ Pollut, 245, 820, 2019.

29. YIN H., ZHU J. In situ remediation of metal contaminated lake sediment using naturally occurring, calcium-rich clay mineral-based low-cost amendment. Chemical Engineering Journal, 285, 112, 2016.

30. MASUD M.M., BAQUY M.A., AKHTER S., SEN R., BARMAN A., KHATUN M.R. Liming effects of poultry litter derived biochar on soil acidity amelioration and maize growth. Ecotoxicol Environ Saf, 202, 110865, 2020.

31. CHEN Z., ZHANG X., MA Y., SONG Y., LI Y., GENG G., HUANG Y. Anammox biofilm system under the stress of $\mathrm{Hg}(\mathrm{II})$ : Nitrogen removal performance, microbial community dynamic and resistance genes expression. J Hazard Mater, 395, 122665, 2020.

32. GAO J., ZHANG X., YU J., LEI Y., ZHAO S., JIANG Y., XU Z., CHENG J. Cr(VI) removal performance and the characteristics of microbial communities influenced by the core-shell Maifanite/ZnAl-layered double hydroxides (LDHs) substrates for Chromium-containing surface water. Biochemical Engineering Journal, 160, 107625, 2020.

33. HUANG J., ZHANG W., FAN R., LIU Z., HUANG T., LI J., DU T., XIONG T. Composition and functional diversity of fecal bacterial community of wild boar, commercial pig and domestic native pig as revealed by $16 \mathrm{~S}$ rRNA gene sequencing. Arch Microbiol, 202 (4), 843, 2020. 